\title{
Reviewed Article: The death of an infant chimpanzee at Bossou,
} Guinea

$\operatorname{AUTHOR}(\mathrm{S})$ :

Matsuzawa, Tetsuro

CITATION:

Matsuzawa, Tetsuro. Reviewed Article: The death of an infant chimpanzee at Bossou, Guinea. Pan Africa News 1997, 4(1): 4-6

ISSUE DATE:

1997-06

URL:

http://hdl.handle.net/2433/143350

RIGHT:

Copyright (C) Pan Africa News. 


\section{Reviewed Article:}

\section{The death of an infant chimpanzee} at Bossou, Guinea

Tetsuro Matsuzawa Primsate Research Institute, Kyoto University (matsuzaw@pri.kyoto-u.ac.jp)

\section{Embracing a dead infant}

This is an episode illuminating the strong bond between mother and infant chimpanzees. A 2 -year-old female infant died. The mother 
continued to carry the dead infant even after it mummified. It was 1992, from January to February.

I observed the pair for 16 days before the death and for 27 days following the death.

The mother was named Jire, an approximately 35-year-old female. The infant was named Jokro. There was an older sister, named Ja, 8-year-old. There had been an older brother named Jieza. He would have been 13year-old, but he had already left two years earlier when he had reached the age of 11. Therefore, the three chimpanzees, a mother and two female offspring were living together in the Bossou community, Guinea.

Bossou is located close to the equator, but it is very cool in winter season. Although the temperature reaches 30 degree in a daytime, it falls to 15 degree before the sun rises. There were large temperature differences within a day. It was also dry and dusty, so that the chimpanzees in this community often caught a cold this season.

Jokro seemed to have a sever cold. She ate almost nothing, and sometimes suck milk from the mother's breast. She sit alone and looked up the sky. The sister, Ja, approached to Jokro to play with. One time, the mother showed behavior of extending the arm to touch the forehead of the infant. It looked as if she measured the fever.

Jokro were gradually weakened and finally fell on the ground in front of me. The sister Ja took the hand of Jokro and tried to hold her up. Then, the mother came and held up the infant's hand to bring her up to the back. Jokro was still alive. However, she can no more sit by herself. The mother selected to place the infant softly on the ground which was covered by fallen leaves. Finally, Jokro died. It was the night of January 24th.

On the 25th afternoon, Jire came to the outdoor laboratory for nut-cracking where I was waiting from morning till evening. She carried the dead infant on the back. The dead infant can not cling any more. Jire took the left hand of Jokro and held it between her neck and shoulder. Jire walked away tilting her neck slightly toward the left side.

The chimpanzees built nests in the tree in the night. Jire made a nest by bending and breaking the branches of a tree. She lay in the supine position and then held the dead infant on her chest. She groomed the face of the infant for a while and then slept: Jire, waved the hand to carefully chase away the flies around the rotten carcass at day time, so that the carcass was dried up and turned to be like a mummy.

Because the dead infant no more sucked the nipple, the bottom of the mother became swelling. The menstrual cycle returned. The body was ready to have another baby. Males in the community stood in bipedal position, showed the erected penis, and stamping the ground with the heel as the courtship display: Jire, started to take a rest in the daytime together with the alpha male of the community while she put aside the mummy infant. However, she returned to the infant after taking the rest. She then held the mummy again on her back and walked away.

Not all the chimpanzee mothers behaved like Jire. There might be several reasons. Firstly, it was the dry season so that the rotten carcass was not decomposed and the whole shape remained intact. Secondly, the infant was 2.5- year-old. It means that she reached to the weaning age and started to behave independently from her mother. Mothers who had an infant of this age can be relatively reluctant to be away from the infant. The mother has not always to hold the infant 24 hours a day. There might be some other reasons accidentally coincided with each other, then Jire happened to continue keeping the dead infant. Although the physiological mechanism showed that she was ready to have another baby, she showed a strong tie to the infant. Jire's behavior reminded me of the mother's affection to the infant and the will to keep the carcass.

\section{Pretense of taking care of a sick infant}

When Jokro was really ill, I found very interesting behavior of "pretense" by $\mathrm{Ja}$, the older sister. Jire was observed to carry the sick infant, and moved from one tree to the other. Ja was following the mother. Ja stopped at a huge tree, Aningeria. She shaked a dead branch of the Aningeria tree and got a rod of about $50 \mathrm{~cm}$ long and $10 \mathrm{~cm}$ in diameter. Ja took the rod on her shoulder and then followed the mother. Ja moved the rod from her shoulder to the place under the upper arm to hold it. She stopped at a big horizontal branch to take a rest. The rod was placed on the blanch just to be balanced on it. She slapped the rod by one hand several times, just like softly slapping the back of an infant. Ja moved in the trees at least about $100 \mathrm{~m}$ then moved away and was out of sight.

Ja seemed to actually manipulate the rod as if it were a $\log$ doll. Eventually, the native Manon people at the village Bossou also have the log dolls like this. Manon girls usually hold a rod on their backs as a doll. The log doll is just a rod but has some actual hairs on the top. Ja seemed to pretend to take care of the sick sister just the mother did.

All the details of the episodes of Jokro's 
death was described in an article written in Japanese 1 . This is the translation from the summarized report published in Japanese in a book ${ }^{2}$. Most of the episodes was video-recorded and/or the pictures were also taken. Some of the episodes were put together to make a film and it was on air in Japan in 1992. However, some interesting episodes were missing in the above described summary. For example, the alpha male of the community once used the carcass as a tool for charging display. A 6.5-year-old male played with the carcass while the mother slept in a tree in the day time. The juvenile male took the carcass and climbed a tree and then dropped it from the place of about $5 \mathrm{~m}$ high. Then, he rushed down to the ground to get the carcass. He again climbed the tree with it and winded it rigorously and then dropped it and rushed down. He repeated this behavior. It reminded me of an actual chase play by the juvenile and an infant of 2.5-year-old. For further information, contact the author. Thanks are due to $\mathrm{Y}$. Sugiyama for his guidance and to $\mathrm{J}$. Koman, T. Camara, and G. Goumy for their assistance in the field research.

\section{References}

1. Matsuzawa, T., 1992. The death of an infant and the care by wild chimpanzees at Bossou. Hattatsu (Development) 50: 95-104. (in Japanese)

2. Matsuzawa, T., 1995. Chimpanzee being, Iwanami-shoten publisher, Tokyo, pp.121-126. (in Japanese) 